\title{
超音速平面ジェットの音響場に対する斜めモードの影響
}

\section{Effects of oblique modes on sound flied in a supersonic plane jet}

\author{
$\bigcirc$ 正 渡辺大輔 (広大院工) 正 前川 博 (広大院工)
}

Daisuke WATANABE, Hiroshima University, Kagamiyama 1-4-1, Higashi-Hiroshima 739-8527

Hiroshi MAEKAWA, Hiroshima University, Kagamiyama 1-4-1, Higashi-Hiroshima 739-8527

Key Words: supersonic jet, spatial DNS, transition, unstable mode

1 はじめに 高マッハ数のジェットからの音響放射はマッハ 波によって支配されていることが実験によって報告されている (1).さらに，このマッハ波は乱流中の渦構造 (または波) が超音 速で移動することにより発生していると考えられ，マッ八波に よる騒音は線形安定性モードによってモデル化されている。ま た，超音速平面ジェットにおいて，Kelvin-Helmholtz 不安定性 に起因する二次元およびジェット軸との成す角が小さい反対称 モードの位相速度は超音速であり，マッ八波形成に大きく影響 している，という報告が線形安定性解析並びに時間発展 DNS による研究 ${ }^{(2)}$ によりなされている.しかし，放射されるマッ 八波の効率的な抑制手法はまだ確立されておらず，超音速ノズ ルの設計において克服すべき最も重要な課題の一つとしてあげ られる。 そのため, 矩形ジェットなどの円形とは異なる形状の ジェットについて, 遷移機構および騒音発生機構の理解を深め ることは，超音速ジェットにおける騒音低減技術向上に対し非 常に重要であると考えられる.

このような背景から本研究では，円形ジェットとは異なる 形状の流れである超音速平面ジェットの非定常三次元空間発展 DNS を用い, ランダム攪乱と超音速平面ジェット特有の不安定 波の空閒的発達が流れ場および音響場に及ぼす影響を詳細に調 べる.

2 計算方法 移流マッ八数 $M c=1.17$, ジェット半幅 $b$ に基づ $<R e_{b}=1000$ の平面ジェット空閒発展 DNS における流入摚乱 として, (1)ランダム攪乱 (ランダムケース)および(2)ランダム攪乱 に線形安定解析から得られる位相速度が音速以下の三次元反対称 モードを加える (固有関数ケース) 二通りのケースを用いた。支配 方程式はデカルト座標系で記述された圧縮性ナビェ・ストークス 方程式であり，移流項に 5 次精度散逸コンパクトスキーム (3) を 適用した.また、時間進行には， 4 次精度 4 段階 Runge-Kutta 法 を用いた。 また，計算領域は， $0<x_{1}<60 b,-20 b<x_{2}<20 b$, $0<x_{3}<12 b$ とした. このとき，スパン方向計算領域は線形安 定性解析より求めた最も不安定な斜めモードが 2 波長入る長さ とした. 格子数は $N_{x_{1}} \times N_{x_{2}} \times N_{x_{3}}=401 \times 301 \times 200$ であ り，主流および主流垂直方向に格子伸長を行っている．流出境 界には特性波解析に基づく $\mathrm{NSCBC}^{(4)}$ を適用した。

3 計算結果 図 1(a,b) は，それぞれランダムケースおよび固 有関数ケ一スにおける渦構造の発達の様子である. 固有関数ケー スでは，図中丸で示した $\Lambda$ 状の構造が現われ，ランダムケース より渦構造が複雑化する位置が上流に移る。 また, 図 2 に示さ れるジェット平均速度分布をみるとポテンシャルコアの消失位 置も上流に移動する. 図 3 はジェット近傍の圧力変動レベルで ある. 三次元反対称モードを加えたケースにおいて約 $5 \mathrm{~dB}$ 程度 の圧力変動レベル低下が認められる.これらのことから，三次
元反対称モードは超音速平面ジェットの流れ場および音響場に おいて大きく影響を及ぼすことが分る。

(a)

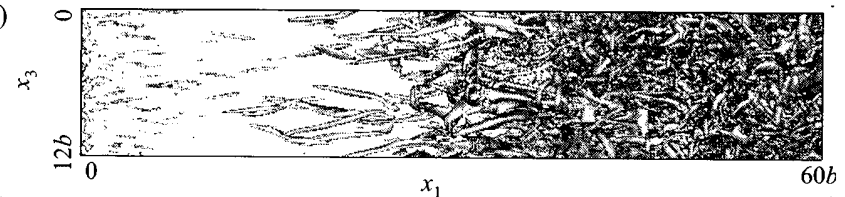

(b)

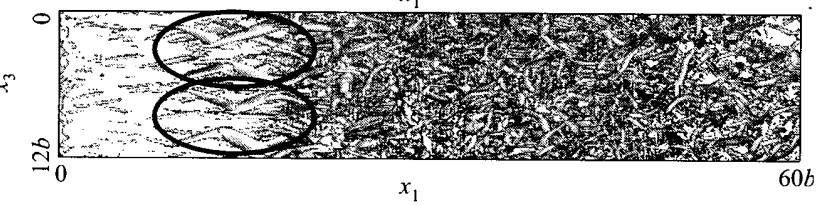

Fig. 1: Downstream evolution of second invariant $Q$ structure (topview) for a) random case and b) eigenfunction case.

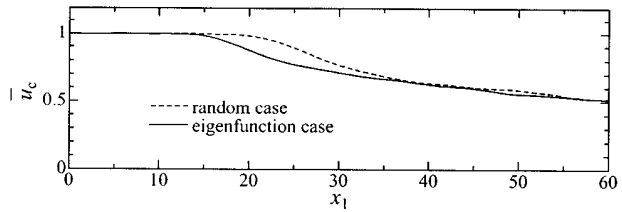

Fig. 2: Jet mean centerline velocity.

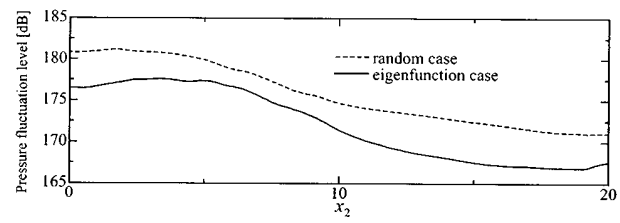

Fig. 3: Pressure fluctuation level $[\mathrm{dB}]$ at $x_{1}=45 b$

\section{参考文献}

(1) Tam C K W., Supersonic Jet Noise., Annu. Rev. of Fluid Mech., 27(1995), 17-43.

(2) Watanabe D. and Maekawa H., Transition of Supersonic Plane Jet due to Symmetric/Antisymmetric Unstable Modes., Journal of Turbulence, 3, 047(2002), 1-17.

(3) Deng X, Maekawa H and Shen C., A Class of High Order Dissipative Compact Schemes., AIAA Paper, No. 961972(1996), 1-11.

(4) Poinsot T J and Lele S K., Boundary Conditions for Direct Simulations of Compressible Viscous Flows., J. Comput. Phys., 101(1992), 104-128. 